\title{
Ascorbic Acid, Folic Acid, and Potassium Content in Postharvest Green-flesh Honeydew Muskmelons: Influence of Cultivar, Fruit Size, Soil Type, and Year
}

\author{
Gene E. Lester ${ }^{1}$ \\ U.S. Department of Agriculture, Agricultural Research Service, Kika de la Garza Subtropical Agricultural \\ Research Center, 2413 East Business Highway 83, Building 200, Weslaco, TX 78596
}

Kevin M. Crosby ${ }^{2}$

Texas A \& M, Texas Agricultural Experiment Station, 2415 East Business Highway 83, Weslaco, TX 78596

AdDitional INDEX WORDs. Cucumis melo (Inodorus Group), 5-methyl-tetrahydrofolic acid, phytonutrients

\begin{abstract}
Two important chemicals and an essential mineral (phytonutrients) for human health and well-being are ascorbic acid, 5-methyl-tetrahydrofolic acid (folic acid) and potassium. The influence of cultivar, fruit size, soil type and year on these compounds in [Cucumis melo L. (Inodorous Group)] was determined. Fully mature (abscised) commercial size fruit: 4, 5, 6, 8, and 9 (fruit/ $0.031 \mathrm{~m}^{3}$ shipping box) from three commercial cultivars: Mega Brew, Morning Ice, and TAM Dew Improved (TDI); and one experimental hybrid 'TDI' $x$ 'Green Ice' were grown on both clay loam and sandy loam soils. Total ascorbic acid and folic acid content increased with an increase in fruit size up to a maximum (size 6 or 5), then decreased with further fruit size increase. Total ascorbic acid and folic acid content for most fruit sizes were higher when grown on clay loam versus sandy loam soils. The experimental hybrid compared to the commercial cultivars contained generally higher total ascorbic acid levels and significantly higher folic acid levels regardless of fruit size or soil type. Free ascorbic acid and dehydroascorbic acid contents were generally higher from clay loam versus sandy loam soils and in the experimental line versus the commercial cultivars. However, free ascorbic acid content was high in small fruit and remained unchanged with an increase in fruit size until size 6 or 5 then significantly decreased; while dehydroascorbic acid content linearly increased with an increase in fruit size. Potassium content averaged $1.7 \mathrm{mg} \cdot \mathrm{g}^{-1}$ fresh weight for each line and did not significantly differ due to fruit size, but did for soil type and year. Analyses of variance for the phytonutrients assayed demonstrated that cultivar (genetics) always was very highly significant $(P=0.001)$, whereas, soil and year (environment) were not.
\end{abstract}

Adietrich in plant foods provides an abundance of phytonutrients: compounds synthesized only by plants or accumulated in plants, and which are critical for their known human wellness effects. Fruit and vegetables are especially rich in three of these important nutrients: ascorbic acid, folic acid, and potassium (Craig and Beck, 1999). Ascorbic acid, first isolated from plants in 1928, has an important role in the human body as a water-soluble antioxidant (Lavine, 1986). Ascorbic acid is critical in maintaining a healthy immune system by reducing the severity of a cold, preventing secondary viral or bacterial complications and protecting against damage by free radicals (Larsen, 1997), and in the prevention of cardiovascular disease (Eichholzer et al., 2001).

Folic acid was first isolated in 1941 from spinach (Spinacia oleracea L.), and characterized as pteroylmonoglutamic acid, a complex water-soluble B vitamin (Cossins, 2000). Folic acid helps in the transport of amino acids to the appropriate location in protein chain creation (Kelly, 1998), is involved in methylation of amino acids, DNA, and RNA (Lucock et al., 1996; Ma et al., 1997); regenerates methionine from homocysteine-an important risk factor in cardiovascular disease-(Leclerc et al., 1998); is involved

Received for publication 20 Nov. 2001. Accepted for publication 21 May 2002. This research was funded by the USDA-ARS under CRIS number 6204-43000007-00D to G.E.L and by the South Texas Melon Committee to K.M.C. We are grateful to the following for their participation and technical support in this study: David Hanna and Robert Meyer (USDA-ARS, Weslaco), and Rick Hernandez and Jin Suk Lee (TAES, Weslaco). Use of company or product names by the USDA or Texas Agricultural Experiment Station does not imply approval or recommendations of the product to the exclusion of others which also may be suitable.

${ }^{1}$ Research plant physiologist; e-mail: glester@weslaco.ars.usda.gov.

${ }^{2}$ Assistant professor, plant breeder; e-mail: k-crosby@tamu.edu. in cell division, differentiation, and regulation (Henning et al., 1997); and regulates the central nervous system, mood, sleep and appetite (Bottiglieri et al., 2000). There is now good evidence that links the deficiency in maternal folic acid status with neural tube defects (spinabifida) in infants (Scott et al., 2000).

Potassium, which is freely absorbed from the soil and easily translocated throughout the plant (Tisdale and Nelson, 1975), is currently identified in the literature as human health-promoting electrolyte (Tunstall-Pedoe, 1999). Potassium is involved in insulin secretion (Agular-Bryan et al., 2001), reducing high blood pressure (Bulpitt, 2000), coronary heart disease (Tunstall-Pedoe, 1999), stroke (Sobey and Faraci, 2001), and hardening of the arteries (Mathew and Lerman, 2001).

Melon (Cucumis melo L.) fruit (honeydew and netted muskmelon) are second only to banana (Musa $\times$ paradisica $\mathrm{L}$.) as the most consumed fruit (bananas $=13.3 \mathrm{~kg} /$ capita vs. melons $=12.4 \mathrm{~kg} /$ capita) in the United States (Lucier, 2001). Melons are rated as a good to excellent source of ascorbic acid, folic acid, and potassium (Richter, 2000). Although these phytonutrients have been detected in melons, little is known as to how factors such as cultivar, fruit size, and production soil type affect ascorbic acid, folic acid and potassium contents in harvested fruit.

The purpose of this study was to determine how these factors may affect ascorbic acid, folic acid and potassium content in fully mature green-fleshed honeydew muskmelons.

\section{Materials and Methods}

Plant material. Seeds of honeydew cultivars Mega Brew, Morning Ice, and TAMDew Improved (TDI), and one experimental hybrid 'TDI' x 'Green Ice' were planted and grown on black plastic 
covers with drip irrigation during two consecutive years on clay loam and sandy loam soils by a commercial grower near Weslaco, Texas. Irrigation was supplied as needed. Soil type and soil mineral analyses were determined by a local, commercial soil testing laboratory. Fruit, free of defects were harvested at maturity (abscission) and separated into marketing size classes: 9, 8, 6, 5 and 4, representing the number of fruit fitting a commercial honeydew melon shipping box $\left(0.031 \mathrm{~m}^{3}\right)$. Five fruit (replications) were sampled for each size class, from each cultivar, grown on each soil type, each year.

Phyotnutrient assays. Middle-mesocarp tissue segments, from the fruit equator with the rind and seed tissues removed, were cut into $1-\mathrm{cm}^{3}$ segments, frozen immediately in liquid nitrogen and stored under nitrogen at $-80^{\circ} \mathrm{C}$ until extraction. Each phytonutrient was determined from a specific weight of tissue obtained from the pooled three segments.

Free ascorbic acid and dehydroascorbic acid were extracted from $7.5 \mathrm{~g}$ of frozen tissue in $15 \mathrm{~mL}$ ice-cold $5 \%$ (w/v) meta-phosphoric acid and homogenized using a polytron homogenizer (Brinkman Instruments, Westbury, N.Y.) at medium speed for $5 \mathrm{~s}$. Homogenized tissue was centrifuged at $7000 g_{n}$ for 15 min at $4{ }^{\circ} \mathrm{C}$. Detection of free ascorbic acid and dehydroascorbic acid was at $525 \mathrm{~nm}$ according to Hodges et al. (2001) and concentrations were calculated using a standard curve.

Folic acid, assayed as 5-methyl-tetrahydrofolic acid(G.R. Beecher and R.F. Doherty, personal communication), was extracted from 7.5 $\mathrm{g}$ of frozen melon tissue in $20 \mathrm{~mL}$ of $4{ }^{\circ} \mathrm{C}$ extraction buffer $(0.1 \mathrm{M}$ potassium phosphate, $10 \mathrm{~mm}$ 2-mercaptoethanol, $10 \mathrm{~mm}$ ascorbic acid, and $10 \mathrm{mg} \cdot \mathrm{L}^{-1}$ sodium azide) adjusted to $\mathrm{pH} 6.0$ with $85 \%$ $\mathrm{H}_{3} \mathrm{PO}_{4}$ and homogenized using a polytron homogenizer at medium speed for $10 \mathrm{~s}$. Homogenized tissue was filtered through two layers of Masslin Towel (Chicopee, New Brunswick, N.J.) under slight vacuum. The filter was washed with $5 \mathrm{~mL}$ extraction buffer and combined with the filtrate. Reconstituted rat plasma $(0.1 \mathrm{~mL})$ was added, held at $21^{\circ} \mathrm{C}$ for $10 \mathrm{~min}$ to cleave folic acid polyglutamyl forms to monoglutamyl then the mixture was capped and heated in a $90^{\circ} \mathrm{C}$ water bath for 15 min to denature the rat plasma. After cooling to room temperature, the mixture was centrifuged at 40,000 $g_{n}$ for $25 \mathrm{~min}$. The resulting supernatant was decanted and diluted to 50 $\mathrm{mL}$ with extraction buffer. Twenty milliliters of the supernatant was applied to a solid phase extraction column containing $500 \mathrm{mg}$ styrene divinylbenzene (Alltech, Deerfield, Ill.) previously wetted, and washed with extraction buffer. After loading fruit folates onto the column, the column was washed with $15 \mathrm{~mL}$ extraction buffer and folic acid, as 5-methyltetrahydrofolic acid, was eluted with $6 \mathrm{~mL} 1$ $\mathrm{N}$ HCL containing $25 \%(\mathrm{v} / \mathrm{v})$ acetonitrile into a tube containing $0.2 \mathrm{~mL}$ triethylamine. The 5-methyl-tetrahydrofolic acid extract solution was bubbled with nitrogen gas for $30 \mathrm{~min}$ at $50^{\circ} \mathrm{C}$, to reduce the volume to $5 \mathrm{~mL}$. The 5 methyl-tetrahydrofolic acid was analyzed by high-performance liquid chromatography with a flow rate of $1 \mathrm{~mL} \cdot \mathrm{min}^{-1}$ using an adsorb-

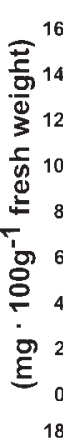

osphere 15-cm × 4.6-mm column (C18 UHS 5; Alltech, Deerfield, Ill.) and a programmed mobile phase: $5 \mathrm{~min}$ at $100 \% 30 \mathrm{~mm}$ potassium phosphate containing $10 \mathrm{mg} \cdot \mathrm{L}^{-1}$ sodium azide (potassium phosphate buffer, $\mathrm{pH} 2.2$ ); then a 20 min gradient to $80 \%: 20 \%$ $(\mathrm{v} / \mathrm{v})$ potassium phosphate buffer to acetonitrile, then a 5 min step gradient to $60 \%: 40 \%(\mathrm{v} / \mathrm{v})$ potassium phosphate buffer to acetonitrile, followed by $5 \mathrm{~min}$ of $100 \%$ potassium phosphate buffer. Fluorescence detection was at $290 \mathrm{~nm}$ excitation and $350 \mathrm{~nm}$ emission with a photomultiplier gain setting of 12. External standard 5-methyl-tetrahydrofolic acid (Sigma Chemical Co., St. Louis, Mo.) was used for standard curve and retention time determinations.

Potassium was determined on ashed tissue (10 $\mathrm{g}$ fresh weight) following the instructions of the flame photometer (model PFP-7; Jenway Ltd., Felsted, Dunmow, Essex, U.K.).

STATISTICS. Analysis of variance was used to evaluate treatment differences for melon lines, fruit size, soil type, and year data (SAS Institute, Cary, N.C.). Data are expressed as the average of five singlefruit replications per cultivar, per fruit size, per soil type, per year.

\section{Results and Discussion}

Comparison of different honeydew muskmelon commercial fruit sizes from three cultivars and one breeding line grown on clay loam and sandy loam soils demonstrated that fruit size, cultivar and

Fig 1. Changes in total ascorbic acid, free ascorbic acid, and dehydroascorbic acid in harvested honeydew melons of different commercial sizes from different lines grown on clay loam versus sandy loam soils in 2001. Vertical bars \pm SE $(n=5)$.
Clay Loam Soil

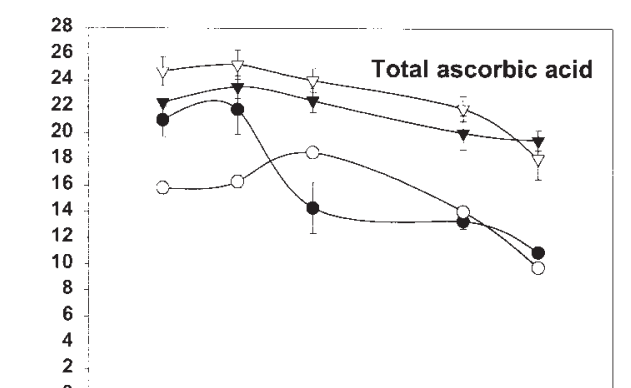

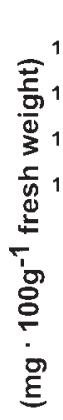$$
16
$$$$
\begin{array}{r}
16 \\
14 \\
12 \\
10 \\
8 \\
6 \\
4 \\
2 \\
0
\end{array}
$$

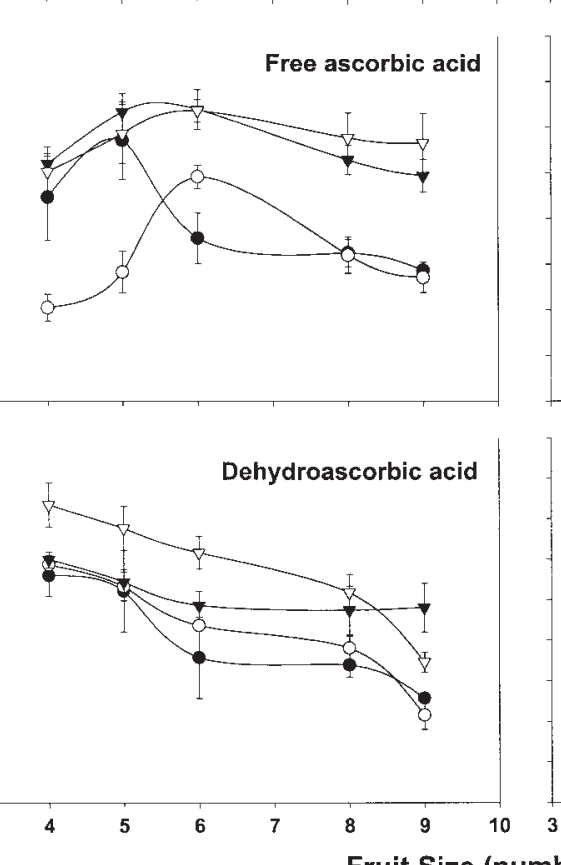

\section{Sandy Loam Soil}
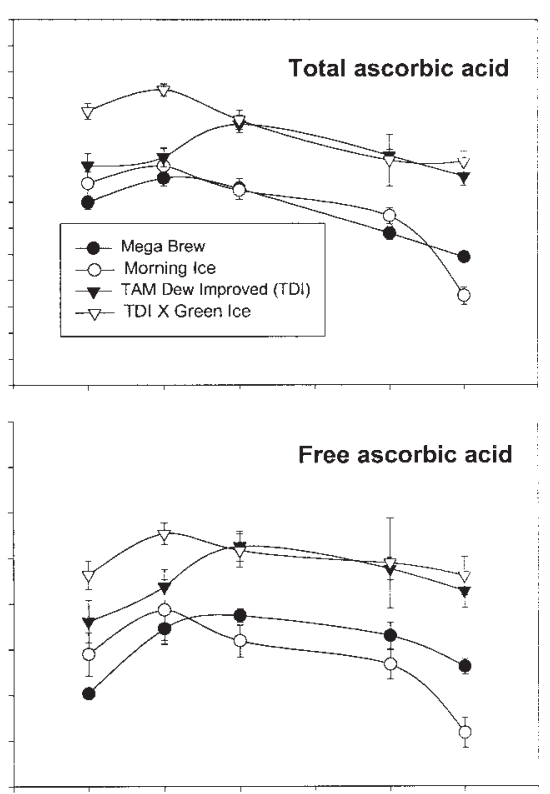

Dehydroascorbic acid

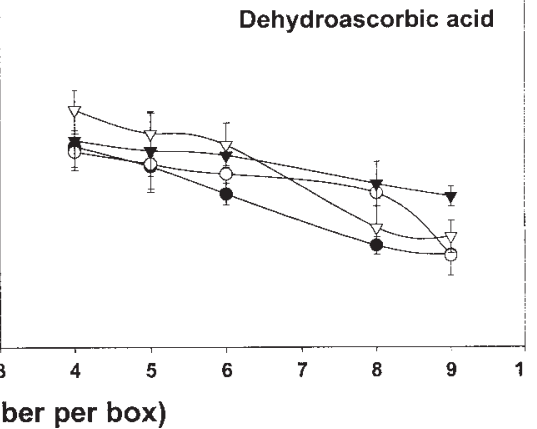


Table 1. Analyses of variance of four honeydew cultivars grown on clay loam or sandy loam soils with five commercial fruit sizes harvested in 2000 and 2001 for evaluation of total ascorbic acid (TAA), ascorbic acid (AA), dehydroascorbic acid (DAA), folic acid (FA) and potassium (K) contents.

\begin{tabular}{|c|c|c|c|c|c|}
\hline \multirow[b]{2}{*}{ Source } & \multicolumn{5}{|c|}{ Mean square } \\
\hline & TAA & AA & DAA & FA & $\mathrm{K}$ \\
\hline$\overline{\text { Cultivar (C) }}$ & $593.1^{* * * *}$ & $296.3^{* * *}$ & $79.0^{* * * *}$ & $2241.6^{* * * *}$ & $0.483^{* * * *}$ \\
\hline $\mathrm{C} \times \mathrm{F}$ & $115.0^{* * * *}$ & $21.5^{*}$ & $48.6^{* *}$ & $211.0^{\mathrm{NS}}$ & $0.241^{* *}$ \\
\hline Soil (S) & $110.9^{* *}$ & $2.7^{\mathrm{NS}}$ & $87.8^{* * *}$ & $3008.2^{* * * *}$ & $0.317^{*}$ \\
\hline $\mathrm{C} \times \mathrm{S}$ & $29.0^{\mathrm{NS}}$ & $37.4^{* * *}$ & $48.6^{* * *}$ & $803.7^{* * *}$ & $0.180^{*}$ \\
\hline $\mathrm{C} \times \mathrm{Y}$ & $96.6^{* *}$ & $27.5^{*}$ & $28.1^{\mathrm{NS}}$ & $429.1^{\mathrm{NS}}$ & $0.060^{\mathrm{NS}}$ \\
\hline
\end{tabular}

$\overline{\mathrm{NS},{ }^{*}, * *, * * * *}$ Nonsignificant or significant at the $P \leq 0.05,0.01$. or 0.001 respectively.

soil type affected total ascorbic acid (TAA), free ascorbic acid (AA) and dehydroascorbic acid (DAA) contents (Fig. 1), and that these affects, except for AA by soil type, were significant (Table 1). Total ascorbic acid was relatively low in the smallest fruit size (9) regardless of cultivar or breeding line or soil type. As fruit size increased TAA also increased until size 6 or 5 (depending on cultivar or breeding line) then significantly decreased with fruit size 4. A similar curve response in TAA content has been found in tomatoes (Lycopersicum esculentum Mill.), in response to fruit ripening (Giovanelli et al., 1999), and with $\beta$-carotene content in orangeflesh, netted muskmelons with fruit size (Lester and Eischen, 1996). The curve response for TAA content, over melon size, can be associated with changes in AA and DAA contents. Depending on cultivar or breeding line, AA exhibited a curve response to fruit size. It remained relatively unchanged until fruit size 6 , then decreased in size 5 (except 'Morning Ice') and a further decrease occurred in the largest fruit size (4). The DAA content did not exhibit a curve response to fruit size, but a linear response, as it is lowest in the smallest fruit size (9) and highest in the largest fruit size (4). The curves of TAA, AA and DAA contents with honeydew melon due to fruit size were similar whether grown on clay loam or sandy loam soils. The effect of soil type on TAA, AA, and DAA was significant for TAA, and DAA content. Fruit TAA and DAA content, regardless of cultivar or breeding line, was generally lower in sandy loam than in clay loam soil. The relative concentration differences of TAA, AA and DAA attributable to each cultivar and breeding line, at each fruit size, were reproducible on both soil types. For TAA and AA, the breeding line 'TAM Dew Improved' $x$ 'Green Ice' always had the highest concentrations, regardless of soil type or fruit size. Although not always different in TAA and AA concentrations than its maternal parent, 'TAM Dew Improved', the breeding line had higher concentrations than cultivars Mega Brew and Morning Ice. The DAA concentrations were very highly significant $(P=0.001)$ for cultivar effect and were generally highest in the breeding line.

The 5-methyl-tetrahydrofolic acid (folic acid) content was significantly affected by cultivar, fruit size, and soil type (Table 1), and the curve response (Fig. 2) resembled that of TAA (Fig. 1). Folic acid was lowest in the smallest fruit size (9), increased with increasing fruit size up to a maximum in fruit sizes 6 or 5 then declined in the largest fruit size 4 . This aforementioned curve pattern was more pronounced, and with higher concentrations, in fruit produced on clay loam versus sandy loam soil.
Potassium concentration although significantly affected by cultivar and soil type was not affected by fruit size (Table 1). Potassium concentration did not differ with an increase in fruit size (Fig. 2). Potassium content, however, when averaged across all fruit sizes and melon lines, was higher in fruit from clay loam than sandy loam soil (1.8 vs. $1.5 \mathrm{mg} \mathrm{K} / \mathrm{g}$ fresh weight, respectively). This overall difference in potassium content, in clay loam versus sandy loam soil produced fruit, reflects the difference in potassium content naturally in the soil (Table 2).

The year effect determined using only fruit size 6 from all lines grown on clay loam soil was significant for TAA, AA, and DAA (Table 1). Total ascorbic acid, AA and DAA contents were higher in 'Mega Brew' and 'TAMDew' (except for AA) produced in 2000 versus 2001 (Fig. 3). 'Morning Ice' and the breeding line had low and high concentrations, respectively, of each ascorbic acid form and these concentrations were not significantly influenced by the environmental effect of years.

The year effect for folic acid, and potassium was determined using only fruit size 6 from the fruit lines grown on clay loam soil (Table 1). Folic acid was not significantly influenced by the year effect, but potassium was. Nevertheless, folic acid was higher in cultivars Mega Brew and Morning Ice produced in 2000 than in

Fig 2. Changes in 5-methyl-tetrahydrofolic acid (folic acid) and potassium (K) in harvested honeydew melons of different commercial sizes from different lines grown on clay loam versus sandy loam soils in 2001 . Vertical bars $\pm \operatorname{SE}(n=5)$.

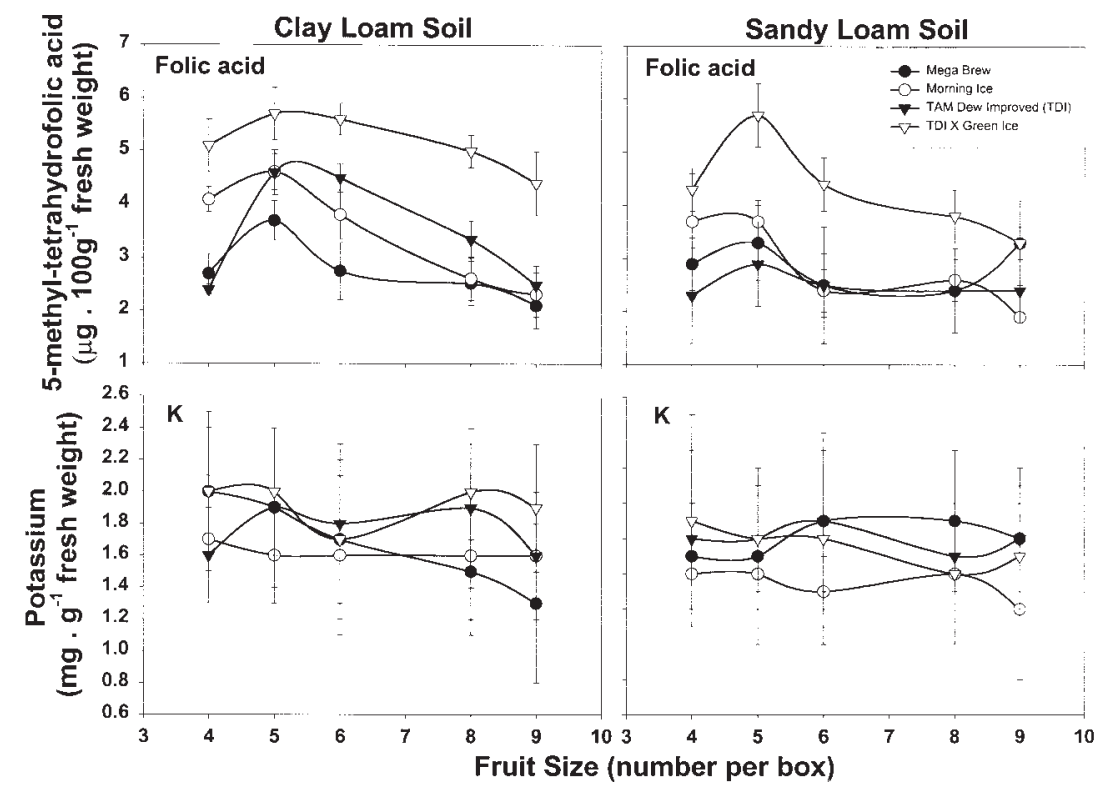


Table 2. Chemical analyses of clay loam versus sandy loam soils used to grow green-flesh honeydew melon lines in 2000 and 2001, Weslaco, Texas.

\begin{tabular}{|c|c|c|c|c|}
\hline Soil type & $\mathrm{pH}$ & $\begin{array}{c}\text { Organic } \\
\text { matter } \\
(\%)\end{array}$ & $\begin{array}{c}\text { Cation } \\
\text { exchange } \\
\text { capacity } \\
(\mathrm{meq} / 100 \mathrm{~g})\end{array}$ & $\begin{array}{c}\text { Potassium } \\
\left(\mathrm{kg} \cdot \mathrm{ha}^{-1}\right)\end{array}$ \\
\hline Clay loam & 8.1 & 1.4 & 41.0 & 1053 \\
\hline Sandy loam & 7.2 & 0.5 & 8.9 & 502 \\
\hline
\end{tabular}

2001, but 'TAM Dew Improved' and the breeding line (which had relatively the highest concentrations) were essentially the same both years (Fig 4).

Potassium concentrations, on average, from fruit produced in

Clay Loam Soil
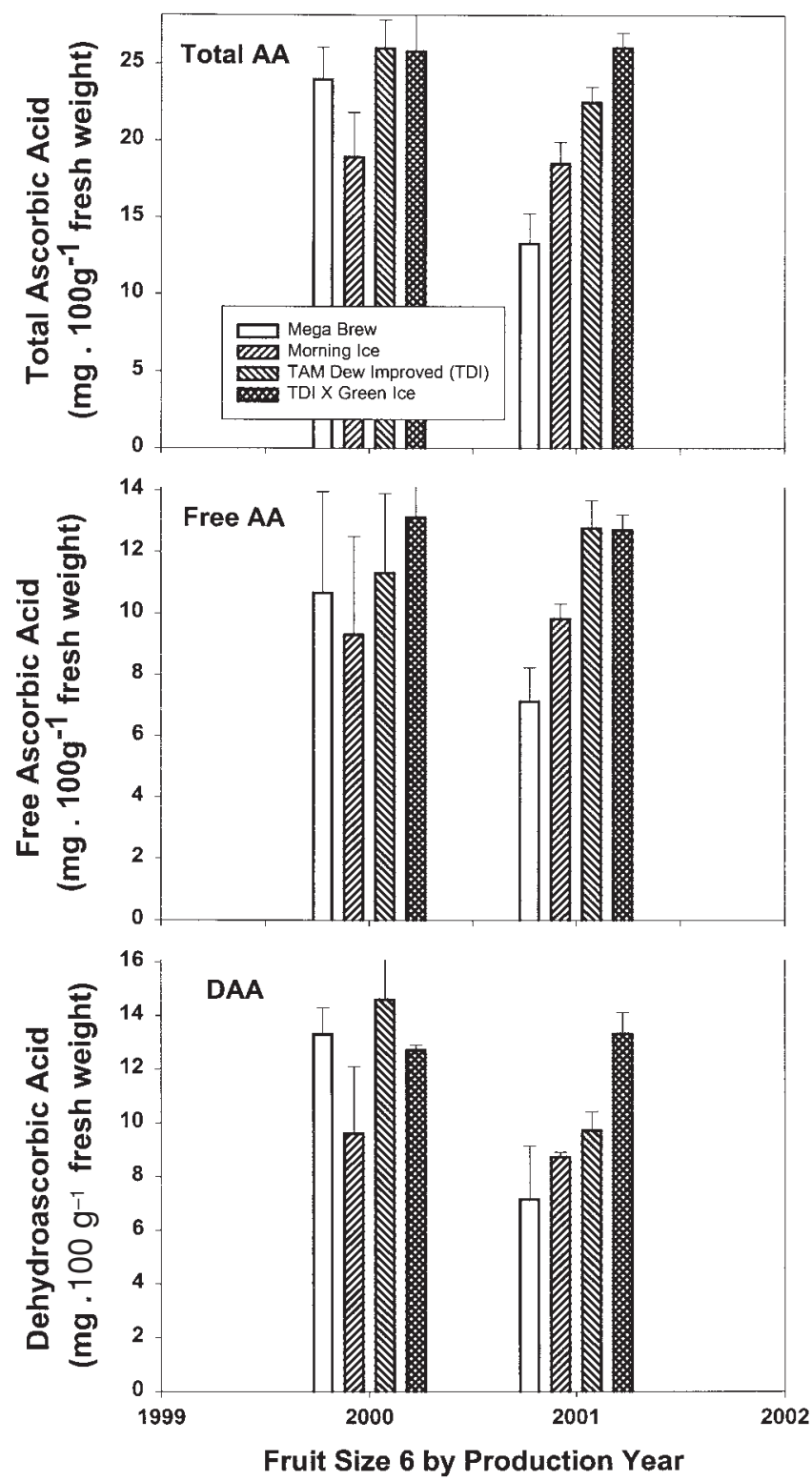

Fig 3. Comparison of total ascorbic acid (Total AA), free ascorbic acid (Free AA) and dehydroascorbic acid (DAA) in harvested honeydew melon size 6 fruit from different lines grown on clay loam soil in years 2000 versus 2001 . Vertical bars $\pm \operatorname{SE}(\mathrm{n}=5)$.
2000 vs. 2001 were slightly higher (2.0 vs. $1.8 \mathrm{mg} \mathrm{K} / \mathrm{g}$ fresh weight, respectively).

There was no difference in the percent dry weight among the melon lines, fruit sizes or soil types. On average, however, fruit produced in 2000 versus 2001 had slightly more dry weight $(10.9 \%$ vs. $10.3 \%$ dry weight respectively).

In conclusion, this study has uniquely shown that phytonutrients TAA, AA, DAA, folic acid, and the element K, in honeydew melons are highly significantly affected by genotype regardless of fruit size, soil type, or production year. But where potassium was not affected by fruit size and AA not affected by soil type, TAA, DAA and folic acid were. Therefore, future reporting of these and other phytochemicals, in honeydew melons should detail not only the

\section{Clay Loam Soil}
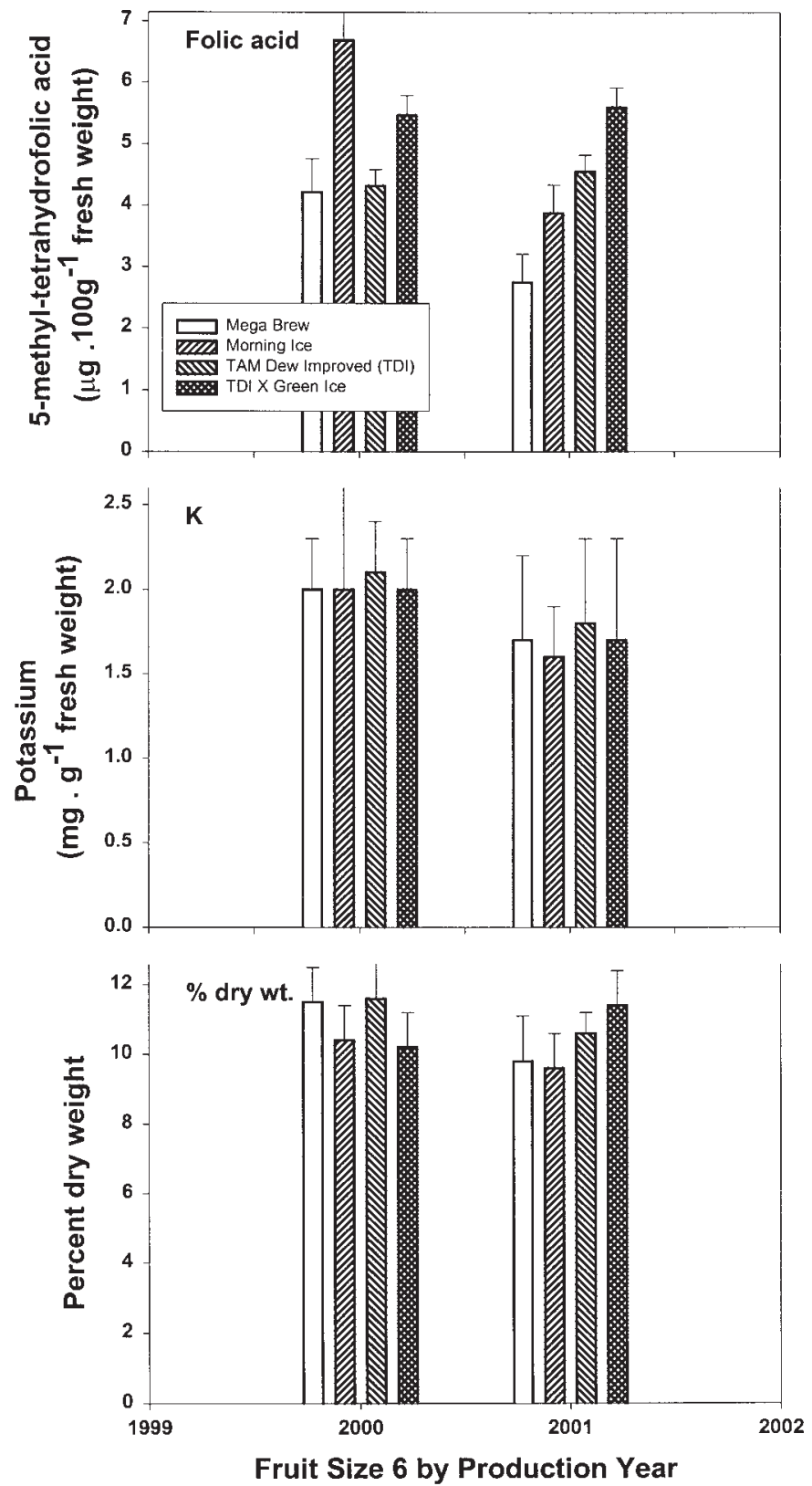

Fig 4. Comparison of 5-methyl-tetrahydrofolic acid (folic acid), potassium (K) and percent dry weight (\% dry weight) in harvested honeydew melon size 6 fruit from different lines grown on clay loam soil in years 2000 versus 2001 . Vertical bars $\pm \operatorname{SE}(n=5)$. 
cultivar grown, but the fruit size assayed and production soil type. The USDA nutrient database for standard reference, reports honeydew melon having TAA of $24.0 \mathrm{mg} / 100 \mathrm{~g}$ fresh weight, folic acid at $6 \mathrm{mg} / 100 \mathrm{~g}$ fresh weight (determined microbiologically), and potassium of $2.7 \mathrm{mg} \cdot \mathrm{g}^{-1}$ fresh weight (USDA-ARS, 2001). When compared with our data, the nutrient database reported values of these phytonutrients are either nearly identical or many fold different in concentration. This demonstrates a potentially considerable variation within the honeydew melon germplasm for these phytonutrients. Evidence of variation for folic acid content among breeding lines and cultivars of red beet (Beta vulgaris L.) is substantial and has been genetically enhanced regardless of environmental (year) effects (Wang and Goldman, 1996). In tomato, positive high heterosis was found for AA content which was tightly linked with high total soluble solids content (Bhatt et al., 2001). If the same holds true for honeydew melons genetically increased AA content will contribute to increased fruit sugar content, and sugars are significantly correlated with overall consumer preference(Lester and Shellie, 1996). The importance of enhancing levels of natural or protective constituents in edible plants is well illustrated in the case of folic acid. There is good evidence that folic acid status even in affluent countries is not optimal (Lindsay, 2000). Enhancement of plant foods for almost all phytonutrients is particularly important as nutritional supplements can have a debilitating or toxic effect, whereas, there is no known toxicity associated with natural (plant ingested) forms of these compounds whether it be for folic acid (Scott et al., 2000) or ascorbic acid (Halliwell, 2001).

Enhancing ascorbic acid, folic acid and potassium concentrations in honeydew melons through breeding appears highly feasible. One cultivar, TAM Dew Improved, and the breeding line always had high concentrations of TAA, AA, DAA, and folic acid and potassium compared to the other fruit lines. These high concentrations were reproducible regardless of environmental effects: soil type or year. Continued research using available germplasm, with divergent phytonutrient concentrations, will be helpful in identifying the genetic or physiological basis for nutrient variation, and in altering inhibitory compounds that reduce the bioavailability of these human wellness compounds (Grusak and DellaPenna, 1999).

\section{Literature Cited}

Agular-Bryan, L., J. Bryan, and M.. Nakazaki. 2001. Of mice and men KAP channels and insulin secretion. Recent Prog. Hormone Res. 56:47-68.

Bhatt, R.P., V.R. Biswas, and N. Kumar. 2001. Heterosis, combining ability and genetics for vitamin $\mathrm{C}$, total soluble solids and yield in tomato (Lycopersicon esculentum) at $1700 \mathrm{~m}$ altitude. J. Agr. Sci. 137:71-75.

Bottiglieri, T., M..Laundy, R. Crellin, B.K. Toone, M.W. Carney, and E.H. Reynolds. 2000. Homocysteine, folate, methylation, and monoamine metabolism in depression. J. Neurol. Neurosurg. Psychiatry 69:228-232.

Bulpitt, C.J. 2000. Blood pressure and potassium consumption. Epidemiol. Hypert. 20:296-312.

Cossins, E. 2000. The fascinating world of folate and one-carbon metabolism. Can. J. Bot. 78:691-708.

Craig, W. and L. Beck. 1999. Phytochemicals: health protective effects. Can. J. Dietetic Practice Res. 60:78-84.

Eichholzer, M., J. Luthy, F. Gutzwiller, and H.B. Stahelin. 2001. The role of folate, antioxidant vitamins and other constituents in fruit and vegetables in the prevention of cardiovascular disease: the epidemiological evidence. Intl. J. Vitamin Nutr. Res. 71:5-17.

Giovanelli, G., V. Lavelli, C. Peri, and S. Nobili. 1999. Variation in antioxidant compounds of tomato during vine and postharvest ripening.
J. Sci. Food Agr. 79:1583-1588.

Grusak, M.A. and D. DellaPenna. 1999. Improving the nutrient composition of plants to enhance human nutrition and health. Annu. Rev. Plant Physiol. Plant Mol. Biol. 50:133-161.

Halliwell. B. 2001. Vitamin C and genomic stability. Mut. Res. 475:29-35. Henning, S.M., M.E. Swendseid, and W.F. Coulson. 1997. Male rats fed methyl- and folate-deficient diets with or without niacin develop hepatic carcinomas associated with decreased tissue NAD concentrations and altered poly (ADP-ribose) polymerase activity 1,2. J. Nutr. 127: 30-36. Hodges, D.W., C.F. Forney, and W.V. Wismer. 2001. Antioxidant responses in harvested leaves of two cultivars of spinach differing in senescence rates. J. Amer. Soc. Hort. Sci. 126:611-617.

Kelly, G.S. 1998. Folates: Supplemental forms and therapeutic applications. Alt. Med. Rev. 3:208-220.

Larsen, H.R. 1997. Vitamin C: your ultimate health insurance. Intl. J. Alt. Complementary Med. 15:22-24.

Lavine, M. 1986. New concepts in the biology and biochemistry of ascorbic acid. New England J. Med. 314:892-902.

Leclerc, D., A. Wilson, R. Dumas, C. Gafuik, D. Song, D. Watkins, H.H.Q. Heng, J.M. Rommens, S.W. Scherer, D.S. Rosenblatt, and R.A. Gravel. 1998. Genetics cloning and mapping of a cDNA for methionine synthase reductase, a flavoprotein defective in patients with homocystinuria. Proc. Natl. Acad. Sci. USA 95:3059-3064.

Lester, G.E. and F. Eischen. 1996. Beta-carotene content of postharvest orange-flesh muskmelon fruit: effect of cultivar, growing location and fruit size. Plant Foods Human Nutr. 49:191-197.

Lester, G.E. and K.C. Shellie. 1992. Postharvest sensory and physicochemical attributes of honeydew melon fruit. HortScience 27:10121014.

Lindsay, D.G. 2000. The nutritional enhancement of plant foods in Europe 'NEODIET'. Food Sci. Technol. 11:145-151.

Lucier, G. 2001. Fruit and tree nut situation outlook report yearbook. Govt. Printing Office, Wash., D.C.

Lucock M.D., I. Daskalakis, C.J. Schorah, M.I. Levene, and R. Hartley. 1996. Analysis and biochemistry of blood folate. Biochem. Mol. Med. 58:93-112.

Ma, J., M.J. Stampfer, E. Giovannucci, C. Artigas, D.J. Hunter, C Fuchs, W.C. Willett, J. Selhub, C.H. Hennekens, and R. Rozen. 1997. Methylenetetrahydrofolate reductase polymorphism, dietary interactions, and risk of colorectal cancer. Cancer Res. 57:1098-1102.

Mathew, V. and A. Lerman. 2001. Altered effects of potassium channel modulation in coronary circulation in experimental hypercholesterolemia. Atherosclerosis 154:329-335.

Richter, H. 2000. Fresh produce guide: nutrition, selection, preparation, storage, handling, cooking. Try-Foods Intl. Inc., Apopka, Fla.

Scott, J., F. Rebeille, and J. Fletcher. 2000. Folic acid and folates: the feasibility for nutritional enhancement in plant food. J. Sci. Food Agr. 80:795-824.

Sobey, C.G. and F.M. Faraci. 2001. Role of potassium in regulation of brain arteriolar tone-Comparison of cerebrum versus brain stem comment. Stroke 32:224-225.

Tisdale, S.L. and W.L. Nelson. 1975. Soil and fertilizer potassium, magnesium, calcium and sodium, p. 243-277. In: Soil fertility and fertilizers. Macmillan, New York, N.Y.

Tunstall-Pedoe, H. 1999. Does dietary potassium lower blood pressure and protect against coronary heart disease and death? Findings from the Scottish heart health study. Sem. Nephrol. 19:500-502.

U.S. Department of Agriculture, Agricultural Research Service. 2001. USDA, nutrient database for standard reference, release 14. Nutrient data laboratory home page, http://www.nal.usda.gov/fnic/cgi-bin/ nut_search.pl.

Wang, M. and I.L. Goldman. 1996. Phenotypic variation in free folic acid content among $\mathrm{F}_{1}$ hybrids and open-pollinated cultivars of red beet. J. Amer. Soc. Hort. Sci. 121:1040-1042. 